\title{
Composition-based view of the firm as a promising approach to studying small businesses
}

\author{
Shehnaz Tehseen ${ }^{\mathrm{a}}$ (D), Sadia Ahmed Mughal ${ }^{\mathrm{b}}$ (D), Susanne Durst ${ }^{\mathrm{c}}$ (D), Muhammad Shujahat ${ }^{\mathrm{d} *}$ (D), \\ Zuhaib Hassan Qureshi ${ }^{\mathrm{b}}$ (D), Panagiotis Kokkalis ${ }^{\mathrm{e}}$ \\ aSunway University, Department of Management, Sunway University Business School, Bandar Sunway, Selangor, Malaysia \\ bUniversiti Kuala Lumpur, Universiti Kuala Lumpur Business School, Kuala Lumpur, Wilayah Persekutuan, Malaysia \\ 'University of Skövde, School of Business, Skövde, Sweden \\ dThe University of Hong Kong, Faculty of Education, Knowledge Management \& E-Learning Lab, Hong Kong, China

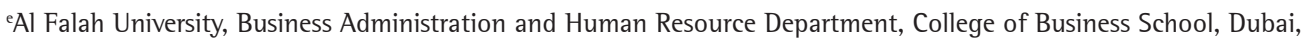 \\ United Arab Emirates \\ *shujahat1993@gmail.com
}

\begin{abstract}
Paper aims: Extant Literature based on the resource-based view (RBV) of the firm suggests that it can be used to study organizations of all types and sizes. In essence, the RBV argues that firms that possess rare, non-imitable, valuable, unique, and non-substitutable resources will outperform firms that do not possess such resources. This study questions the applicability of this assumption to smaller businesses, which are likely to have common resources readily available in the market rather than rare, non-imitable, non-substitutable, unique, or valuable resources. The purpose of this study is to discuss whether the composition-based view (CBV) of the firm offers a more promising approach than the RBV to studying small businesses.
\end{abstract}

Originality: This study is one of the first to tentatively suggest a change in theoretical approach when studying small businesses.

Research method: A structured critical review approach is taken.

Main findings: The findings reveal that the CBV offers a more promising and appropriate theoretical framework than the RBV for research on small businesses, whereas the RBV is better suited to research on larger firms.

Implications for theory and practice: Future studies can use the RBV and the CBV to study large and small businesses, respectively.

Keywords

Composition-Based View (CBV). Resource-Based View (RBV). Small businesses. Common resources. Literature review.

How to cite this article: Tehseen, S., Mughal, S. A., Durst, S., Shujahat, M., Qureshi, Z. H., \& Kokkalis, P. (2019). Composition-based view of the firm as a promising approach to studying small businesses. Production, v. 29 , e20180022. <https://doi.org/10.1590/0103-6513.20180022>

Received: Apr. 14, 2018; Accepted: Jan. 2, 2019.

\section{Introduction}

Small and medium-sized enterprises (SMEs) are considered vital to countries' economic development (Neumark et al., 2011; Thurik \& Wennekers, 2004; Day, 2000). The term "SMEs" is most commonly used to describe firms that are not large (Yan, 2015). SMEs are different from micro-enterprises and large firms. A micro-enterprise is defined as a firm that employs fewer than 10 people (Rhodes, 2009). Firms classified as large consist of at least 500 employees (Acs \& Audretsch, 1988). The European Union classifies firms as SMEs based on balance sheet totals, 
annual turnover, and number of employees (Commission of the European Communities, 2005). Any firm with 10 to 49 employees is considered a small firm. A firm with 50 to 249 employees is regarded as a medium-sized firm. Small firms undertake small-scale business activities, have a small share in the market, operate independently, and are personally managed by their owners (Holmes \& Schaper, 2018; Deakins \& Freel, 2003). The central position occupied by the owner-managers of many SMEs (Bridge et al., 2003) implies that only one person in such a firm is responsible for decision making and business planning (Culkin \& Smith, 2000). The owner-manager may possess most of the company's human capital and relational capital (Durst \& Wilhelm, 2011).

A range of studies have investigated the critical factors contributing to the success of small businesses in various contexts. They have examined internal factors/resources, including competencies and human capital, and external factors, such as opportunities and threats (Hausman, 2005; Mazzarol et al., 1999; Yusuf, 1995). These factors have been linked with certain underpinning theories. For instance, internal factors/resources such as capabilities have been linked with the resource-based view (RBV) of the firm (Tehseen et al., 2015). The RBV has also been extensively used in the field of entrepreneurship to describe the success of firms of different sizes. Specifically, the RBV has been used to examine small enterprises (Ahmad et al., 2018), medium-sized firms (Degravel, 2012; Truong, 2010; Westhead et al., 2001), and large firms (Wernerfelt, 2013; Peng \& Jiang, 2010). The literature review suggests that studies have generally used the RBV as the base approach to describing the resources required for a company of any size to achieve success in any area of business. This generalized use of the RBV raises two crucial questions. First, what is the central proposition of the RBV? Second, is the use of the RBV appropriate to and suitable for all types of firm, including small businesses?

In answer to the first question, the RBV attempts to explain how firms gain and maintain unique and sustainable positions within extremely competitive environments (Barney, 1991; Hoopes et al., 2003). The central proposition of the RBV is that achieving a competitive advantage is desirable, to which end firms compete based on their internal capabilities and resources (Barney, 1991; Wernerfelt, 1984). Therefore, the RBV holds that a firm with unique, valuable, non-imitable, and rare resources (internal factors) will outperform a firm that does not have such resources (Barney, 1991).

In answer to the second question, this study contests that the RBV is not an appropriate framework for studying all types of firms. It is especially inapplicable to small firms, because the context of small businesses is not aligned with the context of the RBV (its underlying assumptions and propositions). Recently, research has begun to place greater emphasis on contextual factors (such as assumptions, propositions, and limitations) and their impacts (Sergeeva \& Andreeva, 2016). Contextual issues can assist in explaining inconsistencies and controversial findings (Joshi \& Roh, 2009). Thus, a stronger focus on context may also lead to the development of new contingent theories that are context-based and practice-driven (May \& Stewart Junior, 2013; Johns, 2006; Mowday \& Sutton, 1993).

Due to the diverse nature and characteristics of firms of different sizes, a specific theory such as RBV is not suited to the contexts of all types of firm. The distinctive contextual characteristics of small businesses are as follows. First, small businesses quickly respond and adapt to opportunities, shaping and reshaping themselves accordingly (Holmes \& Schaper, 2018). Second, although small businesses are dominant in all economies, little is known about the nature of small businesses because their characteristics differ from those of large businesses (Holmes \& Schaper, 2018). Therefore, considering the context of small businesses is essential. Third, ownership motivations explain the performance of small businesses. Fourth, small businesses provide their owners with a level of control that is not available in large firms (Barringer \& lreland, 2019). Small businesses deal with common types of business that need common resources. Recognizing the inherently qualitative nature of small firms and the ordinariness of their resources is critical to understanding their operations (Holmes \& Schaper, 2018). Small businesses are qualitative in their organization and operation (Jafari et al., 2007; Meredith, 1994).

Embedded in the above-established context of small businesses, this study proposes that the underlying principle of the RBV (i.e., its postulates, assumptions, and limitations) is not aligned with the context of small businesses (for example, the resources held by small businesses differ in type and nature from those of large firms). Consequently, the RBV is not an appropriate framework for studying smaller businesses. For example, unlike large firms, small businesses usually have limited resources. The RBV argues that only firms with valuable, rare, unique, non-substitutable, and non-imitable resources can achieve a competitive advantage or superior performance (Barney, 1991). This argument is not in line with the reality of small businesses, which primarily deal with ordinary resources. In their seminal article on the composition-based view (CBV) of the firm, Luo \& Child (2015, p. 381) defined "ordinary resources" as "resources that are neither idiosyncratic nor costly to copy, and that are tradable in the market and can be purchased in or secured from partner firms." An example of the common resources possessed by small businesses is cheap manual labor (Li, 2018; Barringer \& Ireland, 2019).

Therefore, this study proposes the CBV as an alternative theoretical approach to studying small businesses. Luo \& Child (2015) described the CBV as a unique approach recognizing that firms can grow and achieve success even when they lack critical competencies and do not possess the benefits of market power, resource 
advantages, or core technology. This study proposes that, the CBV is a more suitable and relevant approach than the RBV to studying the small business context.

Accordingly, the purpose of this study is to compare the CBV with the RBV to determine which approach is more appropriate for studying the performance of small businesses. The methodology is a structured literature review. The findings indicate that the CBV is more relevant to small businesses than the RBV.

The research question is as follows.

RQ: Does the CBV offer a more appropriate theoretical framework than the RBV for studying the growth of small businesses?

\section{Methodology}

This study used a structured literature review and discursive analysis of the RBV and the CBV to answer the research question. A structured review is a systematic, step-by-step method that involves planning, conducting, and reporting on a search of the available literature related to a specific topic/research question. This approach has three main phases: planning, conducting, and reporting. The research methodology used in this study was adapted from systematic reviews in previous studies (e.g., Shujahat et al., 2017; Sergeeva \& Andreeva, 2016; Durst \& Edvardsson, 2012). The nature of the research questions in these systematic review studies was similar to that of the question asked in the current study.

The following explicit steps were followed.

1. An initial literature search and review using relevant and diverse search strings in different databases was performed to transform the research idea into a research question sufficiently specific and original to contribute to the literature.

The research question formulated was as follows.

$\mathrm{RQ}$ : Does the CBV offer a more appropriate and promising theoretical framework than the RBV for studying the growth of small businesses?

2. An additional literature review based on the research question was carried out to identify and access seminal references for the RBV and the CBV and other studies that discussed these two theories with particular reference to SMEs and large firms. We used snowball sampling of these seminal and related papers to find other relevant studies.

3. A framework for the study was developed. Answering the research question required two stages of analysis, as detailed below. These two stages were the basis for the study's framework due to their alignment with and appropriateness to the research question. This step was consistent with Shujahat et al. (2017).

(i) The extraction, assimilation and synthesis, and description of the assumptions, postulates/propositions, limitations, and critiques of the two theories with particular reference to small and large firms as contained in the accessed studies.

(ii) Comparative analysis of the contexts, assumptions, postulates, and limitations/critiques of the two theories to determine which theory offered a more promising and appropriate approach to studying small businesses. Therefore, the differences, similarities, and complementarities between the two theories in their assumptions, postulates, and limitations concerning small and large firms were assimilated, synthesized, and reported.

4. Synthesis: using the above framework, all of the relevant data from the abovementioned papers were elicited, synthesized, and reported to answer the research question.

\section{Findings of literature review}

\subsection{RBV}

\subsubsection{Context of RBV}

Organizational strategy plays a vital role in the success of any business. The primary purpose of a business is to develop and use the most effective strategy to achieve a competitive advantage and business success. In the strategic management literature, there are two schools of thought about achieving a competitive advantage. 
According to the first school of thought, businesses are influenced by external factors, including environmental turbulence (Wang \& Fang, 2012; Zhang \& Duan, 2010) and network competence (Li et al., 2016; Parida et al., 2010; Chiu, 2008). Strategic contingency theory has been used in the literature to support this school of thought, which argues that the external business environment influences the success of any business (Lawrence \& Lorsch, 1967).

The other school of thought emphasizes the role of internal factors, including competencies and resources, in attaining superior firm performance (Śmigielska, 2016). The RBV belongs to the latter school of thought, according to which firms achieve success and competitive advantages due to their internal resources. Thus, the resource-based theory investigates the differences in the performance of firms based on their resources and other internal characteristics (Peteraf \& Barney, 2003).

\subsubsection{Assumptions of RBV}

According to Barney (1991), the primary assumptions of the RBV are as follows: (1) the resources held by firms within an industry may differ; and (2) these resources may not be perfectly mobile across firms. Therefore, differences in firms' resources can be very longstanding and constitute a source of advantage.

\subsubsection{Propositions of RBV}

The RBV postulates that an organization can be viewed as the sum of its valuable, rare, non-imitable, and non-substitutable resources, which are crucial to its ability to gain a competitive advantage (Nason \& Wiklund, 2018). Therefore, firms that strategically and continuously acquire, create, share, and utilize resources with these characteristics will outperform those that do not. These postulates are explained in detail below.

The RBV seeks to explain how firms maintain unique and sustainable positions within an intensely competitive environment (Ritter \& Lettl, 2018; Hoopes et al., 2003). The focus of this theory is on efficiency-based differences between firms, instead of differences in other areas, such as strategic behaviors, market power, or collusion (Peteraf \& Barney, 2003). The key idea of the RBV is that competition between firms arises from their capabilities and resources (Ferreira \& Fernandes, 2017; Barney, 1991; Wernerfelt, 1984). A firm can identify its competitors based on the similarity of their products, substitutes, capabilities, and resources (Peteraf \& Bergen, 2003). The RBV assumes that firms' decisions on the choice and assembly of resources are economically rational, with limited biases and prejudices, information and causal ambiguity (Oliver, 1997). Causal ambiguity is the phenomenon whereby a firm does not know how its configuration of resources led to its superior or above-average performance (Miles, 2012).

Wernerfelt (1984) defined a resource as anything that can be considered a firm's strength. The term "resources" covers any intangible or tangible asset that is semi-permanently tied to the firm (Klier et al., 2017; Caves, 1980). Examples of resources are technology, machinery, and intellectual capital (Wernerfelt, 1984). Firms' resources are viewed as the strengths that assist firms in competing effectively with their rivals and implementing successful strategies to attain their visions. Capabilities were initially viewed as a specific type of resource (Ritter \& Lettl, 2018). However, these two concepts were separated in later research. According to Makadok (2001), a capability cannot be observed and is therefore intangible; it cannot be valued; and it moves only as part of the unit in which it is housed. Firms seek to create a unique resource situation to make it difficult for their rivals to compete with them (Wernerfelt, 1984).

Therefore, a firm can attain a competitive position by acquiring and collecting unique resources and relationships (Klier et al., 2017; Rumelt, 1974). A firm's competitive advantage is based on its use of a profitable and value-creating strategy not utilized by its rival firms (Barney, 1991). A competitive advantage turns into a sustainable competitive advantage (SCA) when competing firms are unable to copy or learn about that strategy. A firm's SCA derives from its non-substitutable, unique, valuable, rare, and inimitable capabilities and resources (Barney, 1991). A firm's resource is considered rare when competing firms want it but cannot acquire it. Organizational resources are valuable when they assist a firm in creating or implementing strategies that improve its effectiveness and efficiency (Ritter \& Lettl, 2018). Organizational resources are non-substitutable and inimitable only when they are perfectly immobile across firms and thus cannot easily be traded or transferred in factor markets (Klier et al., 2017). Moreover, they are difficult to accumulate due to their high transaction costs (Capron \& Hulland, 1999). A firm must be able to absorb and use its resources to attain an SCA (Barney \& Clark, 2007; Conner, 1991). Hence, the RVB entails business-level or enterprise-level analysis (Peteraf \& Barney, 2003). This theory shows how a firm's capabilities and resources differentiate its business performance from that of other firms (Ferreira \& Fernandes, 2017). 
The RBV differs from theories that emphasize dyads, such as the employer-employee relationship, the industry level, or the group level (Miles, 2012). Miles (2012) argued that the RBV is not substitutable for other analytic tools at industry level because it mainly focuses on the differences in performance between firms. Firms can be differentiated from other firms in terms of their performance based on their earnings or profitability, which results in resources with different efficiency levels (Ritter \& Lettl, 2018; Barney, 1991; Peteraf, 1993). Only superior resources enable firms to produce good-quality products and amply satisfy their customers. A more efficient firm has lower costs but higher profits, and it can create more value for its customers. Efficiency is measured in terms of net profits or the benefits to a firm that are left after deducting the firm's costs (Miles, 2012). Sustainable competitive advantages and disadvantages can arise via a single purchase or can develop over time (Helfat \& Peteraf, 2003).

Initially, the RBV did not focus on whether resources evolve or remain static. However, recent researchers have placed more emphasis on how resources adapt, change, and evolve. For instance, studies have examined how organizations build, combine, and reconfigure their capabilities and resources to respond to rapidly changing business environments (Nason \& Wiklund, 2018; Klier et al., 2017; Teece et al., 1997). Scholars such as Ferreira \& Fernandes (2017) and Helfat \& Peteraf (2003) have also investigated the dynamic life cycle of a firm's capabilities and resources through its growth from birth to death.

As shown in Figure 1, a firm leverages various resources, intangible and intangible. Although possessing different types of resources is essential to achieve success, not all resources contribute equally to a firm's achievement of success and competitive advantages (Peteraf, 1993; Barney, 1991).

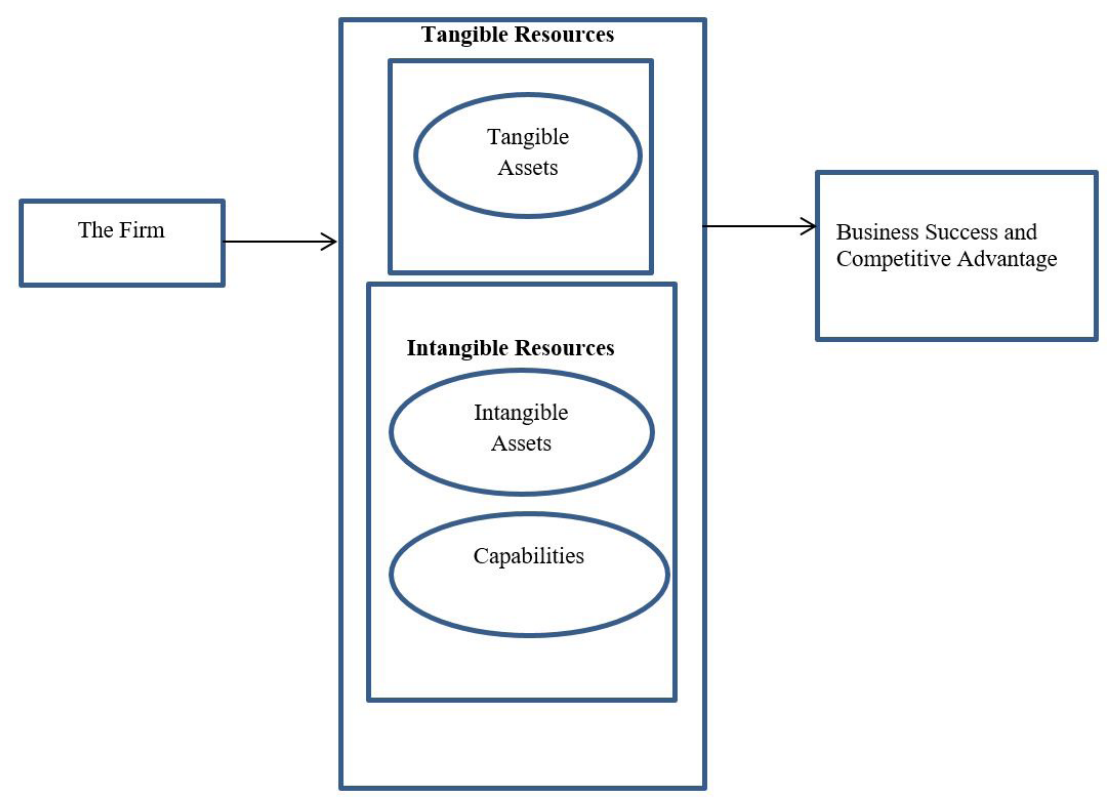

Figure 1. Resource-based view of firms' success, based on Barney (1991) and Peteraf (1993).

\subsubsection{Criticisms and limitations}

The main aspects of the theory to be criticized are as follows.

3.1.4.1. Emphasis on possession of unique, rare, valuable, imitable, and non-substitutable resources

The main assumptions of the RBV relate to medium-sized or large firms that possess unique, rare, valuable, imitable, and non-substitutable resources (Priem \& Butler, 2001). According to this theory, as small businesses usually deal with ordinary types of business and rarely possess rare resources, superior performance may not be 
possible for them (Luo \& Child, 2015). The resources required by small businesses, including physical, human, and organizational assets, are readily available in the market. It has been deduced from the literature that in this embedded context, the RBV is not an appropriate or a promising approach to studying the context of small businesses.

\subsubsection{Attractive simplicity}

The RBV is an attractively simple theory with immediate face validity. Its core ideas are intuitive and appealing and can be easily understood and taught (Kraaijenbrink et al., 2010). However, the RBV has been criticized for its weaknesses. For instance, the theory lacks implications for managers (Priem \& Butler, 2001). It instructs managers to obtain valuable, rare, imitable, and non-substitutable resources, but does not tell them how to do so (Miller, 2003; Connor, 2002). The RBV also assumes that managers can predict the value of their resources in the future and have total control over them. Studies have claimed that this theory is tautological (Lockett et al., 2009; Priem \& Butler, 2001). Some researchers have noted that the RBV claims rather than proves empirically that SCAs and superior performance can be the result of variation in capabilities and resources across firms (Baron \& Ensley, 2006). As mentioned earlier, these resources may be either tangible or intangible assets. In contrast, capabilities are a firm's specific resources, including employees' knowledge, skills, and abilities (Wernerfelt, 1984). Thus, capabilities are intangible assets that keep evolving according to the uncertain business environment and market turbulence.

\subsubsection{Lack of contextual consideration}

Baron \& Ensley (2006) criticized the RBV due to the difficulty of disconfirming the theory. Usually, evidence has been found to support its contention that inter-firm variation in capabilities and resources leads to differences in the ability to achieve an SCA and outstanding performance across firms. However, if any evidence contrary to the RBV is found, it implies that the examined capabilities or resources were not of value or importance.

Critics have also claimed that the RBV does not concentrate on organizational situations or contexts (Sergeeva \& Andreeva, 2016; Priem \& Butler, 2001). This is the most critical deficiency of the theory, because the ways in which a firm's resources are acquired and deployed cannot be separated from the firm's context (Oliver, 1997). The theory does not concentrate enough on from where firms acquire their critical resources (Barney \& Clark, 2007).

\subsubsection{Treating capabilities and resources in the same manner}

Another major criticism of the RBV is that it treats capabilities and resources in the same manner (Kraaijenbrink et al., 2010), irrespective of their nature (dynamic or static). Although capabilities and resources have been differently defined, the RBV treats them both as types of resources. Moreover, it pays insufficient attention to the ways in which different firm resources (in different combinations) contribute in different ways to firms' achievement of SCAs and superior performance (Miles, 2012).

\subsubsection{Criticism regarding sustainable advantages}

(a) Fiol (2001) claimed that competitive advantages can be attained only temporarily because the resources and skills required to create these advantages are constantly changing.

(b) Critics have also argued that valuable, rare, non-imitable, and non-substitutable resources are neither essential nor sufficient to achieve an SCA (Miles, 2012). Only modest empirical support has been provided that such resources lead to an SCA (Newbert, 2007; Armstrong \& Shimizu, 2007). This point indicates that other factors in addition to differences in resources aid in achieving a competitive advantage (Miles, 2012).

(c) Finally, the RBV does not explain the survival of resource-poor firms in today's globally competitive environment (Miles, 2012; Li et al., 2016).

\subsubsection{Lack of directions for managing heterogeneous resources}

Priem \& Butler (2001) also pointed out that the RBV does not provide directions for firms to manage their diverse resources to overcome their weaknesses and enhance their strengths. Through various processes, the firms can obtain resources, bundle them into capabilities, and then utilize them to create several advantages (Morrow et al., 2007). 
A careful look at the above-mentioned limitations and critiques of the RBV helps to deduce that the main critique is from the contingency perspective; that is, in relation to contextual factors. The theory attempts to fit all sizes of organization, but is not applicable to small businesses.

\subsection{CBV}

\subsubsection{Context and assumptions of CBV}

Yadong Luo and John Child proposed this theory in 2015 in an article entitled "A composition-based view of firm growth," published in Management and Organization Review. As the CBV was developed to suit small businesses, the current research was motivated to apply this theory to the context of small businesses.

According to the CBV, firms can develop, compete, and grow without the assistance of core technology, resource advantages, or market power. The CBV focuses on how ordinary firms with common resources (non-imitable, non-idiosyncratic, and inexpensive resources that can be traded with and acquired from and by partner firms) may attain superior business growth by effectively and creatively using available open resources and distinct configured capabilities to enhance the speed of service and price-value ratio for a large number of mass market consumers (Luo \& Child, 2015).

Ordinary firms are resource-poor firms whose growth consists of three stages: surviving, catching up, and outcompeting (Li, 2018). At the survival stage, the ordinary firm generally avoids direct competition with resource-rich firms by trying to differentiate through customer acquisition and resource accumulation. Having survived, an ordinary firm enters the catching-up stage, during which it has to catch up with strong incumbents in terms of both market position and resource possession using the cost leadership strategy and the differentiation strategy. Finally, at the outcompeting stage, an ordinary firm has to gain respect within the industry through radical as well as incremental innovations (Li, 2018).

Ordinary firms, including SMEs, own only ordinary resources; they usually lack strategic assets such as brand awareness or core technologies. Therefore, the main idea of the CBV is that firms can successfully compete, survive, and grow without the "benefit of resource advantages, proprietary technology or market power" (Luo \& Child, 2015, p. 379). This notion is especially applicable to smaller firms in today's marketplace. The focus of this theory is small and medium-sized businesses, especially small businesses/firms. According to Deakins \& Freel (2003), a small firm operates independently, has a small share of the market, and is managed by its owners or part-owners in a personalized way. The ability of small firms to respond quickly to rapid changes in society's business environment gives them an advantage over large firms. This characteristic is known as "flexible specialization," which reflects small firms' ability to be both specialized and responsive to change (Deakins \& Freel, 2003).

\subsubsection{Propositions of CBV}

According to the CBV, firms can achieve a competitive advantage and growth if they can identify and acquire a set of existing common resources in the market and combine them in a way that is creative and rapidly adaptable to the market's needs. It allows firms to cleverly and distinctively compose common/ordinary internal and external resources to generate specific advantages and a distinct developmental path for their business growth. Therefore, available resources such as technologies and brands have no intrinsic importance to or benefits for such firms unless the firms can creatively combine these individual elements to achieve a compositional advantage, allowing them to generate impressive efficiency and speed and superior price-value ratios for customers. This compositional advantage relies on firms' organizational resilience, market intelligence, creative use of imitation, and entrepreneurial ability. Compositional processes involve the integration of low cost and new product functions and their organization to allow a fast response to market turbulence and provide superior value for customers.

Composition-based strategies are effective in attracting and retaining middle-income and low-income consumers in today's global markets. The CBV is considered a pragmatic approach that reflects firms' strengths in understanding their customers' needs. Composition-based strategies involve the art of improvisation. According to Teece (1986), higher returns can be obtained at an early stage in the market by adapting existing products and technologies rather than inventing new ones. A unique compositional capability is a dynamic capability that can be applied in any economy to firms with a relatively low endowment. However, the CBV claims that firms can attain a strong position relative to their rivals by creatively assembling and integrating ordinary, open, 
and generic resources that they possess or purchase. Such firms are savvy in distinctively identifying, acquiring, and combining internal and external ordinary resources to achieve a competitive advantage. The CBV approach is not applicable to large, diversified, and/or resourceful firms because it deals with ordinary firms (Luo \& Bu, 2018; Luo \& Child, 2015).

Wernerfelt (1984) regarded resources as the intangible and tangible organizational assets required to attain a competitive advantage. In this context, "ordinary resources" refer to all assets that can be easily attained from the open market. For instance, most small firms, such as retail firms and restaurants, can easily obtain tangible assets, including required labor (people), and intangible assets, such as entrepreneurial competencies (skills, knowledge, and ability) and capabilities, from the market. These types of resources are not unique, as they are commonly available in the market. For instance, a small retail business needs a workforce, basic skills, knowledge, and the ability to anticipate changes in the market and customers' expectations. A small restaurant needs similar types of resources to conduct its business. These resources can be easily gained from the market due to their ordinary nature. Additionally, the term "ordinary resources" refers to resources that are easy to copy, not unique, and easily accessed or tradable in the market, and can be easily purchased or otherwise acquired from partner firms.

Following the RBV, the term "composition" means the identification, configuration, and integration of diverse sources of resources and different means of competition to generate a competitive advantage, as displayed in extended offerings, superior price-value ratios, and rapid responses to mass markets. Firms that adopt the CBV approach are proficient in composing new but low-cost designs to rapidly respond to market dynamics, developing user-friendly products, and enhancing customer-oriented services. The CBV recognizes that small firms do not possess unique resources, and should thus emphasize the distinctive composition of the ordinary resources available to them (Luo et al., 2011; Chittoor et al., 2009). Figure 2 describes the central theme of the CBV.

\begin{tabular}{|c|c|}
\hline \multirow[t]{2}{*}{$\begin{array}{l}\text { Internal Conditions of Small Businesses } \\
\text { Constraints } \\
\begin{array}{l}\text { Lack of critical resources such as brand, } \\
\text { core technology, capital, and brainpower } \\
\text { for innovation. }\end{array} \\
\text { Conduits } \\
\text { - Access to low-cost resources. } \\
\text { Advantage of organizational } \\
\text { ambidexterity. } \\
\text { - Advantage of structural resilience. } \\
\text { Ability for entrepreneurship and } \\
\text { bricolage. }\end{array}$} & $\begin{array}{l}\text { External Conditions of Small Businesses } \\
\text { Catalysts } \\
\text { - Number of consumers who are sensitive } \\
\text { to function and price of products. } \\
\text { - Technological } \\
\text { standardization/modularization. } \\
\text { - Existence of an open market for } \\
\text { technology. } \\
\text { - Industrial clusters that support } \\
\text { horizontal and vertical activities. } \\
\text { Conduits } \\
\text { - Access to low-cost resources. } \\
\text { - Advantage of organizational } \\
\text { ambidexterity. Advantage of structural resilience. } \\
\text { - Ability for entrepreneurship and } \\
\text { bricolage. } \\
\text { - Yin-yang philosophy and harmony. }\end{array}$ \\
\hline & 15 \\
\hline \multicolumn{2}{|c|}{$\begin{array}{l}\text { CBV } \\
\text { Demonstrates that ordinary firms with common resources can achieve superior performance in the following } \\
\text { ways. } \\
\text { - Compositional Offering-Using open resources to provide customers with amalgamated services, } \\
\text { value, and convenience at a minimum cost. } \\
\text { - Compositional Competition-Combining and integrating various types of competition and then } \\
\text { providing consumers with a higher price-value ratio. } \\
\text { Compositional Capability-Using open or generic resources creatively to develop innovative } \\
\text { business models. }\end{array}$} \\
\hline \multicolumn{2}{|c|}{5} \\
\hline \multicolumn{2}{|c|}{$\begin{array}{l}\text { Returns and Advantages } \\
\qquad \quad \text { Financial advantages - low cost and higher return on investment } \\
: \text { Market advantage-higher price-value ratio } \\
\text { Organizational advantages - flexibility and speed } \\
\text { Limitations and Risks }\end{array}$} \\
\hline
\end{tabular}

Figure 2. Composition-based view of firm growth. Source: adapted from Luo \& Child (2015, p. 399). 


\subsubsection{Criticism and limitations of CBV}

Like the RBV, the CBV is not free of limitations. The criticisms leveled against it are as follows.

\subsubsection{Emphasis on emerging economies}

The CBV has been criticized for its primary focus on enterprises in emerging economies, such as firms in the Chinese context (Burton et al., 2015; Volberda \& Karali, 2015).

\subsubsection{Focus on common conduits}

Second, scholars have criticized the key dimensions of the CBV, such as access to low-cost resources, structural resilience, ambidexterity advantage, entrepreneurial ability, harmony, and bricolage (the enduring experience or practice of using available resources to survive under institutional pressure and hardship (Luo \& Bu, 2018; Fang, 2012). Burton (2015) argued that these dimensions/conduits are not very new and do not illustrate creative composition because each has been claimed to offer a solution to various challenges faced by firms.

\subsubsection{3. $\mathrm{CBV}$ as a theory of survivability}

Similarly, entrepreneurial ability and an effective culture are essential for all firms (Burton, 2015). Burton (2015) argued that the CBV describes a survival game played by firms against rivals, with challenges requiring them to make flexible choices to survive in an intensely competitive and turbulent environment. Thus, he considered the CBV to be more about firms' survival than their growth, and argued that survival is a fundamental and critical concept for managers (Burton, 2015). Moreover, he argued that growth is not a key dimension of the theory.

\subsubsection{CBV as a subset of RBV}

Volberda \& Karali (2015) argued that the deployment of compositional capabilities to integrate ordinary resources fits well with the RBV. Thus, the CBV can be considered an extension of the RBV. According to the authors, firms' management teams are accountable for combining ordinary resources in effective and creative ways to achieve growth via competitive advantages. Therefore, compositional capabilities are viewed as a unique type of capability within the RBV.

\subsubsection{Three main deficiencies of CBV}

Li (2016) identified three deficiencies of the CBV: unclear positioning, the abstract nature of the concept of compositional capability, and self-imposed constraints. For instance, Li (2016) criticized the CBV for its unclear positioning and highlighted two aspects of this limitation. First, it is unclear whether the CBV is a new general theory of firms or a specific new theory of firms' growth or strategies. Second, it is unclear whether it is specific to resource-poor firms from a particular region only or can be applied to all types of resource-poor firms. Similarly, the abstract nature of the notion of compositional capability may dilute the innovativeness of the CBV, and fails to capture the processes and mechanisms of how resource-poor firms survive. The time dimension of the evolution of compositional capability was given insufficient attention by Luo \& Child (2015). They overemphasized common and external resources and did not view a temporary competitive advantage as a prerequisite for building a compositional capability perspective.

\subsection{Comparison of RBV and CBV}

Table 1 presents a comparison of the CBV and the RBV in a summarized form.

The CBV differs from the RBV in the following specific ways.

(1) Unlike the RBV, the CBV does not focus on the ownership of superior strategic resources as a precondition for building a competitive advantage. The ordinary resources emphasized by the CBV are not unique and are easy to copy, as they can be purchased in an open market, whereas the RBV perceives ordinary resources as establishing competitive parity, a defensive strategy that helps a business to protect its competitive position or brand without overspending. 
(2) RBV emphasizes the importance of critical resources without offering a mechanistic explanation of the effective utilization or leveraging of such resources. In contrast, the composition process is a critical capability and unique competence that is heterogeneous, valuable, and not very easy to copy. It creates firm-specific benefits. These compositional benefits are temporary. However, the CBV acknowledges that a firm's central goal is to amplify strategic resources and capabilities, as stated by the RBV.

(3) The CBV recognizes two complementary components. The first is the compositional strategy and the second deals with the processes of implementation. These processes enable the firms to organize and integrate internal as well as external resources to yield outputs that capitalize on market opportunities.

(4) External resources can be accessed through various social networks. The CBV complements the RBV because it does not focus on the possession of superior, unique, rare, and imitable resources as a crucial condition for firms to achieve a competitive advantage. The RBV recognizes the importance of generic or open resources to the routine operations of firms but does not view them to be a source of a sustained competitive advantage for them (Barney, 1991). In contrast, the CBV stresses the utilization of multiple sources of open or generic resources, i.e., resources that can create at least a temporary competitive advantage for a firm using creative composition. The RBV regards valuable capabilities and common resources as the basis of competitive parity, not as a source of competitive advantage.

(5) The RBV highlights that resources must be possessed by firms to enable them to formulate and implement effective strategies to enhance their performance. The CBV does not emphasize the ownership of resources by firms. However, it suggests that firms can easily buy resources without incurring a cost disadvantage from the market or partner firms.

Table 1. Comparison of CBV and RBV.

\begin{tabular}{lll}
\hline \multicolumn{1}{c}{ CBV } & \multicolumn{1}{c}{ RBV } \\
\hline Differences & $\begin{array}{l}\text { Emphasizes the process and importance of composting and } \\
\text { integrating ordinary or generic resources/capabilities that are } \\
\text { not owned by firms. }\end{array}$ & $\begin{array}{l}\text { Focuses on the possession of resources as the prerequisite } \\
\text { for gaining a competitive advantage. }\end{array}$ \\
$\begin{array}{ll}\text { Contends that firms can identify, leverage, and integrate } \\
\text { both internal and external ordinary resources to create a } \\
\text { unique growth path. Moreover, the CBV argues that these } \\
\text { ordinary resources can be easily copied as they are available } \\
\text { in the open market. }\end{array}$ & $\begin{array}{l}\text { Assumes that ordinary resources can only establish a position } \\
\text { of competitive parity. }\end{array}$ \\
$\begin{array}{ll}\text { Emphasizes products' extended features, strong } \\
\text { responsiveness to market, and high price-value ratio. }\end{array}$ & $\begin{array}{l}\text { Describes the importance of critical resources possessed by } \\
\text { firms but does not explain how they are leveraged by firms. } \\
\text { Assumes that composition process is a critical capability. }\end{array}$ & $\begin{array}{l}\text { Holds that the composition process is a unique competency } \\
\text { and a critical capability that is heterogeneous, valuable, and } \\
\text { difficult to copy. Thus, it creates a firm-specific advantage. } \\
\text { Complementarity }\end{array}$ \\
$\begin{array}{ll}\text { Considers the temporary advantage of the composition } \\
\text { process. }\end{array}$ & $\begin{array}{l}\text { Assumes that a compositional advantage cannot be held } \\
\text { permanently. Therefore, the ultimate goal of any firm is to } \\
\text { build strategic capabilities and resources. }\end{array}$ \\
\hline
\end{tabular}

Source: adapted from Luo \& Child (2015, p. 385).

\subsection{Justification for using CBV to study context of small businesses}

The above literature review suggests that the CBV is more suitable than the RBV for studying small businesses, for the following reasons (Luo \& Child, 2015).

(1) The CBV emerged from the context of emerging economy enterprises in China. However, it is also applicable to the context of small businesses in other developing and emerging economies, because small businesses in these economies have similar characteristics (Luo \& Child, 2015).

(2) The CBV provides useful insights for businesses that lack critical resources and can be managed via ordinary resources. It shows that small businesses can integrate both internal and external resources to survive and grow.

(3) Furthermore, past studies have considered the CBV a theory of survivability. Small businesses in various developing and emerging economies operate in turbulent business environments in which they face the critical issue of survivability due to intense competition and economic challenges. It is essential for managers and entrepreneurs 
to know how to survive in such a dynamic business environment. This study proposes that the CBV can help such businesses to secure their survival through existing resources.

For instance, entrepreneurial competencies, innovativeness, and network competence are essential resources for businesses, but they are neither rare nor unique and are easy for rivals to copy or substitute. Therefore, these resources exist in all businesses and are easily accessible within the business environment. Small businesses have to develop the networking competence required to gain such critical resources from their networks, such as suppliers, customers, and government organizations.

(4) The CBV is more relevant than the RBV to firms that have only common resources, such as smaller firms. Johnson et al. (2007) noted that the RBV focuses on the degree to which firms seek to achieve competitive advantages by enhancing their strategic information and knowledge from external as well as internal sources. However, they also argued that a firm cannot hold competitive benefits if its rival firms can also access such sources of information. Knowledge and information should be utilized at the right time to solve a given issue, suggesting that firms that access external information resources and then combine their internal resources may be able to achieve competitive advantages in the short term and within their specific competitive business environments (Johnson et al., 2007).

(5) This study argues that the critical postulates of CBV, including access to low-cost resources, structural resilience, organizational ambidexterity, entrepreneurial ability, harmony, and bricolage (innovation and creativity) are relevant to the context of small businesses not only in China but also in other developing and emerging economies. These critical postulates of the CBV for small businesses are explained below.

Small businesses in specific industries have to access low-cost resources due to their financial constraints and the limited scope of their business activities. They also need to provide their customers with services or products at a reasonable cost. Structural resilience is another feature of successful small businesses, which should have flexible organizational structures to cope with and recover from challenges in the turbulent business environment. Similarly, organizational ambidexterity is essential for small businesses, enabling them to manage their ongoing business activities as effectively and efficiently as possible according to the business environment. Entrepreneurial abilities or competencies have also been associated with the survival, growth, and success of small businesses (Ahmad et al., 2010). Several studies have highlighted collectivity and harmony as fundamental cultural values of various small businesses (Lim, 2001). Therefore, this study argues that the CBV is more suitable than the RBV as an approach to studying the context of small businesses.

\section{Conclusion}

The purpose of this study was to to determine whether the CBV or the RBV is more appropriate as an approach to studying small firms. Accordingly, the CBV and the RBV were compared using a structured literature review. It was observed from the literature that RBV is the most common theory of the firm; it has been widely used to describe the phenomenon of small businesses' success. The success of small businesses has been studied in terms of intangible and tangible resources, such as competencies, innovation, and intellectual capital. These resources, along with characteristics such as high value, rarity, non-imitability, and non-substitutability, have often been associated with the RBV. Small businesses deal with ordinary resources, such as innovative practices, competencies, and even various capabilities. However, as these are common and easily available in the market, they are neither rare, unique, nor imitable, but can be easily substituted. Therefore, the RBV has been criticized by scholars for failing to explain the success of small firms. This study argues that CBV is the most appropriate theoretical framework for describing the growth of small businesses through the combination of various ordinary resources.

\subsection{Implications}

The RBV is a relatively widely used theory because it has many theoretical extensions (such as the knowledge-based view of the firm and the talent-based view of the firm) in sub-disciplines of management and business (such as strategic management, knowledge management, and talent management). Therefore, the theoretical implications of this study are fairly easy to extend to these sub-disciplines. The CBV is particularly promising as an approach to studying small businesses because these businesses have common resources. The RBV and its extensions offer more promising means of studying large firms that possess valuable, unique, 
non-imitable, rare, and non-substitutable resources, rather than common resources, that can provide them with a competitive advantage.

The main practical implication of this study is as follows. Whereas large firms can gain a competitive advantage by striving to obtain valuable, unique, non-imitable, rare, and non-substitutable resources, smaller businesses should combine their common resources in sufficiently novel ways to gain a competitive advantage. Small businesses can integrate internal and external common resources to become competitive in the marketplace.

\subsection{Limitations and future recommendations}

This study provides the following recommendations for future research studies. First, the research question asked in the study should be further investigated using other methodologies, such as interviews with academics with expertise in the field. Second, in the context of the CBV, researchers could investigate (1) when firms decide to recombine their resources, (2) when firms stop recombining their resources to develop new resources, and (3) when firms allow common resources to be replaced to facilitate new product lines. Third, it would be interesting to explore whether such decisions are made differently across businesses (Volberda \& Karali, 2015). Finally, in line with Volberda \& Karali (2015), this study suggests that future studies should investigate in depth whether only small firms require compositional capabilities. Medium-sized and large firms also need to synthesize and integrate diverse resources, including open resources, to exploit opportunities to attain a competitive advantage.

\section{References}

Acs, Z. J., \& Audretsch, D. B. (1988). Innovation in large and small firms: an empirical analysis. The American Economic Review, 78, 678-690.

Ahmad, N. H., Ramayah, T., Wilson, C., \& Kummerow, L. (2010). Is entrepreneurial competency and business success relationship contingent upon business environment? A study of Malaysian SMEs. International Journal of Entrepreneurial Behaviour \& Research, 16(3), 182-203. <http://dx.doi.org/10.1108/13552551011042780>

Ahmad, N. H., Suseno, Y., Seet, P. S., Susomrith, P., \& Rashid, Z. (2018). Entrepreneurial competencies and firm performance in emerging economies: A study of women entrepreneurs in Malaysia. In V. Ratten, V. Braga, \& C. S. Marques (Eds.), Knowledge, learning and innovation (pp. 5-26). Cham: Springer. <http://dx.doi.org/10.1007/978-3-319-59282-4_2>.

Armstrong, C. E., \& Shimizu, K. (2007). A review of approaches to empirical research on the resource-based view of the firm. Journal of Management, 33(6), 959-986. <http://dx.doi.org/10.1177/0149206307307645>

Barney, J. (1991). Firm resources and sustained competitive advantage. Journal of Management, 17(1), 99-120. <http://dx.doi. org/10.1177/014920639101700108>

Barney, J., \& Clark, D. (2007). Resource-based theory: creating and sustaining competitive advantage. New York: Oxford University Press.

Baron, R. A., \& Ensley, M. D. (2006). Opportunity recognition as the detection of meaningful patterns: Evidence from comparisons of novice and experienced entrepreneurs. Management Science, 52(9), 1331-1344. <http://dx.doi.org/10.1287/mnsc.1060.0538>

Barringer, B. R., \& Ireland, R. D. (2019). Entrepreneurship: successfully launching new ventures (6th ed.). New Jersey: Pearson Prentice-Hall.

Bridge, S., O'Neill, K., \& Cromie, S. (2003). Understanding enterprise, entrepreneurship and small business (2nd ed.). Basingstoke: Palgrave Macmillan.

Burton, R. M. (2015). Extraordinary survival from ordinary resources - how so? Management and Organization Review, 11(3), 413-417. $<$ http://dx.doi.org/10.1017/mor.2015.38>

Burton, R. M., Obel, B., \& Håkonsson, D. D. (2015). Organizational design: a step by step approach. Cambridge: Cambridge University Press. <http://dx.doi.org/10.1017/CB09781316160787>.

Capron, L., \& Hulland, J. (1999). Redeployment of brands, sales forces, and general marketing management expertise following horizontal acquisitions: a resource-based view. Journal of Marketing, 63(1), 41-54. <http://dx.doi.org/10.1177/002224299906300203>

Caves, R. E. (1980). Industrial organization, corporate strategy and structure. Journal of Economic Literature, 18(1), 64-92.

Chittoor, R., Sarkar, M. B., Ray, S., \& Aulakh, P. S. (2009). Third-world copycats to emerging multinationals: Institutional changes and organizational transformation in the Indian pharmaceutical industry. Organization Science, 20(1), 187-205. <http://dx.doi. org/10.1287/orsc.1080.0377>

Chiu, Y. T. H. (2008). How network competence and network location influence innovation performance. Journal of Business and Industrial Marketing, 24(1), 46-55. <http://dx.doi.org/10.1108/08858620910923694>

Commission of the European Communities. (2005). Commission recommendation concerning the definition of micro, small and mediumsized enterprises. Official Journal of the European Union, 124, 36-41.

Conner, K. R. (1991). A historical comparison of resource-based theory and five schools of thought within industrial organization economics: do we have a new theory of the firm? Journal of Management, 17(1), 121-154. <http://dx.doi.org/10.1177/014920639101700109>

Connor, T. (2002). The resource-based view of strategy and its value to practicing managers. Strategic Change, 11(6), 307-316. <http:// dx.doi.org/10.1002/jsc.593>

Culkin, N., \& Smith, D. (2000). An emotional business: A guide to understanding the motivations of small business decision takers. Qualitative Market Research, 3(3), 145-157. <http://dx.doi.org/10.1108/13522750010333898>

Day, J. (2000). Commentary - the value and importance of the small firm to the world economy. European Journal of Marketing, 34(9-10), 1033-1037. <http://dx.doi.org/10.1108/03090560010342764>

Deakins, D., \& Freel, M. (2003). Entrepreneurship and small firms (3rd ed.). Berkshire: McGraw-Hill. 
Degravel, D. (2012). Strategy-as-practice to reconcile small businesses' strategies and RBV? Journal of Management Policy and Practice, 13(1), 46.

Durst, S., \& Edvardsson, 1. R. (2012). Knowledge management in SMEs: a literature review. Journal of Knowledge Management, 16(6), 879-903. <http://dx.doi.org/10.1108/13673271211276173>

Durst, S., \& Wilhelm, S. (2011). Knowledge management in practice: insights into a medium-sized enterprise's exposure to knowledge loss. Prometheus, 29(1), 1-16. <http://dx.doi.org/10.1080/08109028.2011.565693>

Fang, T. (2012). Yin yang: a new perspective on culture. Management and Organization Review, 8(1), 25-50. <http://dx.doi.org/10.1 $111 / \mathrm{j} .1740-8784.2011 .00221 . x>$

Ferreira, J., \& Fernandes, C. (2017). Resources and capabilities' effects on firm performance: what are they? Journal of Knowledge Management, 21(5), 1202-1217.

Fiol, C. M. (2001). Revisiting an identity-based view of sustainable competitive advantage. Journal of Management, 27(6), 691-699. <http://dx.doi.org/10.1177/014920630102700606>

Hausman, A. (2005). Innovativeness among small businesses: theory and propositions for future research. Industrial Marketing Management, 34(8), 773-782. <http://dx.doi.org/10.1016/j.indmarman.2004.12.009>

Helfat, C. E., \& Peteraf, M. A. (2003). The dynamic resource-based view: capability lifecycles. Strategic Management Journal, 24(10), 997-1010. <http://dx.doi.org/10.1002/smj.332>

Holmes, S., \& Schaper, M. T. (2018). Small business exposed: the tribes that drive economies. New York: Routledge. <http://dx.doi. org/10.4324/9781315213538>.

Hoopes, D. G., Madsen, T. L., \& Walker, G. (2003). Guest editor's introduction to the special issue: Why is there a resource-based view? Toward a theory of competitive heterogeneity. Strategic Management Journal, 24(10), 889-902. <http://dx.doi.org/10.1002/smj.356>

Jafari, M., Fathian, M., Akhavan, P., \& Hosnavi, R. (2007). Exploring KM features and learning in Iranian SMEs. Vine, 37(2), $207-218$. $<$ http://dx.doi.org/10.1108/03055720710759973>

Johns, G. (2006). The essential impact of context on organizational behaviour. Academy of Management Review, 31(2), 386-408. $<$ http://dx.doi.org/10.5465/amr.2006.20208687>

Johnson, S., Webber, D. J., \& Thomas, W. (2007). Which SMEs use external business advice? A multivariate subregional study. Environment \& Planning, 39(8), 1981-1997. <http://dx.doi.org/10.1068/a38327>

Joshi, A., \& Roh, H. (2009). The role of context in work team diversity research: A meta-analytic review. Academy of Management Journal, 52(3), 599-627. <http://dx.doi.org/10.5465/amj.2009.41331491>

Klier, H., Schwens, C., Zapkau, F. B., \& Dikova, D. (2017). Which resources matter how and where? A meta-analysis on firms' foreign establishment mode choice. Journal of Management Studies, 54(3), 304-339. <http://dx.doi.org/10.1111/joms.12220>

Kraaijenbrink, J., Spender, J. C., \& Groen, A. J. (2010). The resource-based view: A review and assessment of its critiques. Journal of Management, 36(1), 349-372. <http://dx.doi.org/10.1177/0149206309350775>

Lawrence, P. R., \& Lorsch, J. W. (1967). Differentiation and integration in complex organizations. Administrative Science Quarterly, 12(1), 1-47. <http://dx.doi.org/10.2307/2391211>

Li, J., Chen, Z., \& Schøtt, T. (2016). Innovation benefitting exporting: benefit enhanced by transnational networking. International Journal of Business and Globalisation, 16(3), 245-263. <http://dx.doi.org/10.1504/1JBG.2016.075740>

Li, X. (2016, June 15-19). Compositional advantage and strategy: understanding how resource-poor firms survive and thrive. In The Seventh Biennial International Association for Chinese Management Research Conference (1-36). Hangzhou: The International Association for Chinese Management Research - IACMR.

$\mathrm{Li}, \mathrm{X}$. (2018). How emerging market resource-poor firms compete and outcompete advanced country resource-rich rivals: An asymmetry reversing theory. Cross Cultural \& Strategic Management, 25(3), 538-544. <http://dx.doi.org/10.1108/CCSM-08-2016-0155>

Lim, L. (2001). Work-related values of Malays and Chinese Malaysians. International Journal of Cross Cultural Management, 1(2), 209226. <http://dx.doi.org/10.1177/147059580112005>

Lockett, A., Thompson, S., \& Morgenstern, U. (2009). The development of the resource-based view of the firm: a critical appraisal. International Journal of Management Reviews, 11(1), 9-28. <http://dx.doi.org/10.1111/j.1468-2370.2008.00252.x>

Luo, Y., \& Bu, J. (2018). Contextualizing international strategy by emerging market firms: a composition-based approach. Journal of World Business, 53(3), 337-355. <http://dx.doi.org/10.1016/j.jwb.2017.01.007>

Luo, Y., \& Child, J. (2015). A composition-based view of firm growth. Management and Organization Review, 11(03), 379-411. <http:// dx.doi.org/10.1017/mor.2015.29>

Luo, Y., Sun, J., \& Wang, S. L. (2011). Emerging economy copycats: capability, environment, and strategy. The Academy of Management Perspectives, 25(2), 37-56. <http://dx.doi.org/10.5465/amp.25.2.37>

Makadok, R. (2001). Towards a synthesis of the resource-based and dynamic-capability views of rent creation. Strategic Management Journal, 22(5), 387-402. <http://dx.doi.org/10.1002/smj.158>

May, R. C., \& Stewart Junior, W. H. (2013). Building theory with BRICs: Russia's contribution to knowledge sharing theory. Critical Perspectives on International Business, 9(1/2), 147-172. <http://dx.doi.org/10.1108/17422041311299996>

Mazzarol, T., Volery, T., Doss, N., \& Thein, V. (1999). Factors influencing small business start-ups: A comparison with previous research. International Journal of Entrepreneurial Behaviour \& Research, 5(2), 48-63. <http://dx.doi.org/10.1108/13552559910274499>

Meredith, G. G. (1994). Small business management in Australia (4th ed.). Sydney: McGraw Hill.

Miles, J. A. (2012). Management and organization theory: a Jossey-Bass reader (vol. 9). New York: John Wiley \& Sons.

Miller, D. (2003). An asymmetry-based view of advantage: Towards an attainable sustainability. Strategic Management Journal, 24(10), 961-976. <http://dx.doi.org/10.1002/smj.316>

Morrow, J. L., Sirmon, D. G., Hitt, M. A., \& Holcomb, T. R. (2007). Creating value in the face of declining performance: firm strategies and organizational recovery. Strategic Management Journal, 28(3), 271-283. <http://dx.doi.org/10.1002/smj.579>

Mowday, R. T., \& Sutton, R. 1. (1993). Organizational behavior: linking individuals and groups to organizational contexts. Annual Review of Psychology, 44(1), 195-229. <http://dx.doi.org/10.1146/annurev.ps.44.020193.001211> <PMid:19090760>

Nason, R. S., \& Wiklund, J. (2018). An assessment of resource-based theorizing on firm growth and suggestions for the future. Journal of Management, 44(1), 32-60. <http://dx.doi.org/10.1177/0149206315610635> 
Neumark, D., Wall, B., \& Zhang, J. (2011). Do small businesses create more jobs? New evidence for the United States from the National Establishment Time Series. The Review of Economics and Statistics, 93(1), 16-29. <http://dx.doi.org/10.1162/REST_a_00060>

Newbert, S. L. (2007). Empirical research on the resource-based view of the firm: An assessment and suggestions for future research. Strategic Management Journal, 28(2), 121-146. <http://dx.doi.org/10.1002/smj.573>

Oliver, C. (1997). Sustainable competitive advantage: combining institutional and resource-based views. Strategic Management Journal, 18(9), 697-713. <http://dx.doi.org/10.1002/(SICl) 1097-0266(199710) 18:9<697::AlD-SMJ909>3.0.C0;2-C>

Parida, V., Westerberg, M., Ylinenpää, H., \& Roininen, S. (2010). Exploring the effects of network configurations on entrepreneurial orientation and firm performance: an empirical study of new ventures and small firms. Annals of Innovation \& Entrepreneurship, 1(1), 1-13. <http://dx.doi.org/10.3402/aie.v1i1.5657>

Peng, M. W., \& Jiang, Y. (2010). Institutions behind family ownership and control in large firms. Journal of Management Studies, 47(2), 253-273. <http://dx.doi.org/10.1111/j.1467-6486.2009.00890.x>

Peteraf, M. (1993). The cornerstones of competitive advantage: a resource-based view. Strategic Management Journal, 14(3), $179-191$. <http://dx.doi.org/10.1002/smj.4250140303>

Peteraf, M. A., \& Barney, J. B. (2003). Unraveling the resource-based tangle. Managerial and Decision Economics, 24(4), 309-323. $<$ http://dx.doi.org/10.1002/mde.1126>

Peteraf, M. A., \& Bergen, M. E. (2003). Scanning dynamic competitive landscapes: a market-based and resource-based framework. Strategic Management Journal, 24(10), 1027-1041. <http://dx.doi.org/10.1002/smj.325>

Priem, R. L., \& Butler, J. E. (2001). ls the resource-based 'view' a useful perspective for strategic management research? Academy of Management Review, 26(1), 22-40.

Rhodes, J. (2009). A strategic framework for rural micro-enterprise development: the integration of information communication technology (ICT), e-commerce, marketing, and actor-network theory. Perspectives on Global Development and Technology, 8(1), 48-69. <http://dx.doi.org/10.1163/156914909X403180>

Ritter, T., \& Lettl, C. (2018). The wider implications of business-model research. Long Range Planning, 51(1), 1-8. <http://dx.doi. org/10.1016/j.lrp.2017.07.005>

Rumelt, R. P. (1974). Strategy, structure, and economic performance. Cambridge: Harvard University Press.

Sergeeva, A., \& Andreeva, T. (2016). Knowledge sharing research: Bringing context back in. Journal of Management Inquiry, 25(3), 240-261. <http://dx.doi.org/10.1177/1056492615618271>

Shujahat, M., Hussain, S., Javed, S., Malik, M. 1., Thurasamy, R., \& Ali, J. (2017). Strategic management model with lens of knowledge management and competitive intelligence: A review approach. VINE Journal of Information and Knowledge Management Systems, 47(1), 55-93. <http://dx.doi.org/10.1108/VJIKMS-06-2016-0035>

Śmigielska, G. (2016). The role of an entrepreneur in developing an organizational culture fostering innovations. Studia Oeconomica Posnaniensia, 4(5), 54-68. <http://dx.doi.org/10.18559/SOEP.2016.5.4>

Teece, D. J. (1986). Profiting from technological innovation: implications for integration, collaboration, licensing and public policy. Research Policy, 15(6), 285-305. <http://dx.doi.org/10.1016/0048-7333(86)90027-2>

Teece, D., Pisano, G., \& Shuen, A. (1997). Dynamic capabilities and strategic management. Strategic Management Journal, 18(7), 509533. <http://dx.doi.org/10.1002/(SICl) 1097-0266(199708)18:7<509::AID-SMJ882>3.0.C0;2-Z>

Tehseen, S., Sajilan, S., Ramayah, T., \& Gadar, K. (2015). An intra-cultural study of entrepreneurial competencies and smes business success in whole sale and retail industries of Malaysia: a conceptual model. Review of Integrative Business and Economics Research, 4(3), 33-48.

Thurik, R., \& Wennekers, S. (2004). Entrepreneurship, small business and economic growth. Journal of Small Business and Enterprise Development, 11(1), 140-149. <http://dx.doi.org/10.1108/14626000410519173>

Truong, D. (2010). How cloud computing enhances competitive advantages: a research model for small businesses. The Business Review, Cambridge, 15(1), 59-65.

Volberda, H. W., \& Karali, E. (2015). Reframing the compositional capability: a resource-based view on 'a composition-based view of firm growth. Management and Organization Review, 11(3), 419-426. <http://dx.doi.org/10.1017/mor.2015.39>

Wang, M. C., \& Fang, S. C. (2012). The moderating effect of environmental uncertainty on the relationship between network structures and the innovative performance of a new venture. Journal of Business and Industrial Marketing, 27(4), 311-323. <http://dx.doi. org/10.1108/08858621211221689>

Wernerfelt, B. (1984). A resource-based view of the firm. Strategic Management Journal, 5(2), 171-180. <http://dx.doi.org/10.1002/ smj.4250050207>

Wernerfelt, B. (2013). Small forces and large firms: Foundations of the RBV. Strategic Management Journal, 34(6), 635-643. <http:// dx.doi.org/10.1002/smj.2043>

Westhead, P., Wright, M., \& Ucbasaran, D. (2001). The internationalization of new and small firms: a resource-based view. Journal of Business Venturing, 16(4), 333-358. <http://dx.doi.org/10.1016/S0883-9026(99)00063-4>

Yan, S. (2015). A theoretical framework of competitive advantage for SMEs in China under new normal economy. European Scientific Journal, 11(34), 1-12.

Yusuf, A. (1995). Critical success factors for small business: perceptions of South Pacific entrepreneurs. Journal of Small Business Management, 33(2), 68.

Zhang, J., \& Duan, Y. (2010). The impact of different types of market orientation on product innovation performance: Evidence from Chinese manufacturers. Management Decision, 48(6), 849-867. <http://dx.doi.org/10.1108/00251741011053433> 